\title{
Invertebrate Community Response to a Shifting Mosaic of Habitat
}

\author{
David M. Engle, ${ }^{1}$ Samuel D. Fublendorf, ${ }^{2}$ Aaron Roper, ${ }^{3}$ and David M. Leslie, $\mathrm{Jr}^{4}$
}

Authors are ${ }^{1}$ Professor and Chair, Department of Natural Resource Ecology and Management, Iowa State University, Ames, IA 50010, USA; ${ }^{2}$ Professor, Department of Natural Resource Ecology and Management, Oklahoma State University, Stillwater, OK 74078, USA; ${ }^{3}$ Former Graduate Student, Department of Plant and Soil Sciences, Oklahoma State University, Stillwater, OK 74078, USA; and ${ }^{4}$ Unit Leader, US Geological Survey, Oklahoma Cooperative Fish and Wildlife Research Unit, Oklahoma State University, 404 Life Science West, Stillwater, OK 74078, USA.

\begin{abstract}
Grazing management has focused largely on promoting vegetation homogeneity through uniform distribution of grazing to minimize area in a pasture that is either heavily disturbed or undisturbed. An alternative management model that couples grazing and fire (i.e., patch burning) to promote heterogeneity argues that grazing and fire interact through a series of positive and negative feedbacks to cause a shifting mosaic of vegetation composition and structure across the landscape. We compared patch burning with traditional homogeneity-based management in tallgrass prairie to determine the influence of the two treatments on the aboveground invertebrate community. Patch burning resulted in a temporal flush of invertebrate biomass in patches transitional between unburned and patches burned in the current year. Total invertebrate mass was about $50 \%$ greater in these transitional patches within patch-burned pastures as compared to pastures under traditional, homogeneity-based management. Moreover, the mosaic of patches in patch-burned pastures contained a wider range of invertebrate biomass and greater abundance of some invertebrate orders than did the traditionally managed pastures. Patch burning provides habitat that meets requirements for a broad range of invertebrate species, suggesting the potential for patch burning to benefit other native animal assemblages in the food chain.
\end{abstract}

\section{Resumen}

El manejo del apacentamiento se ha enfocado grandemente en promover la homogeneidad de la vegetación a través de la distribución uniforme del apacentamiento, para minimizar las áreas del potrero que son disturbadas severamente o no son utilizadas. Un modelo de manejo alternativo que conjuga el apacentamiento y fuego (por ejemplo, la quema de parches) para promover la heterogeneidad argumenta que el apacentamiento y el fuego interactúan a través de una serie de estímulos positivos y negativos para causar un mosaico de vegetación que cambia en composición y estructura a través del paisaje. Comparamos la quema de parches con el manejo tradicional, que promueve la homogeneidad, en una pradera de zacates altos para determinar la influencia de los dos tratamientos en la comunidad de invertebrados de la superficie del suelo. La quema de los parches resultó en un incremento abundante temporal de la biomasa de invertebrados en los parches en transición entre los parches no quemados y los quemados en el año en curso. La masa total de invertebrados fue aproximadamente $50 \%$ mayor en estos parches en transición, dentro de los potreros con quema de parches en comparación con los potreros con manejo tradicional basado en la homogeneidad. Más aun, el mosaico de parches en los poteros con quema de parches contenía un rango más amplio de biomasa de invertebrados y una mayor abundancia de algunos órdenes de invertebrados que los potreros manejados tradicionalmente. La quema de parches provee un hábitat que reúnen los requerimientos para un amplio rango de especies de invertebrados, sugiriendo el potencial de la quema de parches para beneficiar otros ensambles de animales nativos de la cadena alimenticia.

Key Words: ecosystem management, equilibrium, grasslands, grazing, heterogeneity, landscape ecology, patch dynamics, plant-animal interaction, rangeland

\section{INTRODUCTION}

Little remains of the North American Great Plains ecosystem once maintained by the interaction of fire and grazing herbivores. Grassland fragments and management practices that result in homogenous landscapes reduce the ecological

This research was funded by the Oklahoma Agricultural Experiment Station through project S-1822 and USDA-NRI Managed Ecosystems Program (02-00777). This article is published with the approval of the Director, Oklahoma Agricultural Experiment Station.

At the time of the research, the senior author was Regents Professor, Dept of Plant and Soil Sciences, Oklahoma State University, Stillwater, OK, USA.

Correspondence: David M. Engle, 339 Science II, Dept of Natural Resource Ecology and Management, lowa State University, Ames, IA 50010, USA. Email: dme@iastate.edu

Manuscript received 8 November 2006; manuscript accepted 6 October 2007. value of remaining prairie (Coppedge et al. 2001; Fuhlendorf and Engle 2001). In contrast, heterogeneity, which links pattern in landscapes to ecological processes, should serve as the foundation for conservation and ecosystem management (Pickett et al. 2003).

Frequency and intensity of disturbance are important drivers of ecological processes, biological diversity, and heterogeneity across multiple spatial scales in grasslands that evolved with fire and ungulate grazing (Collins 1992; Fuhlendorf and Smeins 1999). Large herbivores preferentially select recently burned areas within a landscape (Forde et al. 1984; Coppock and Detling 1986; Moe et al. 1990; Wilsey 1996; Coppedge and Shaw 1998), which can be used to manage spatial patterns of cattle grazing over landscapes (Duvall and Whitaker 1964; Archibald and Bond 2004). However, because the spatial scale 
at which fire and grazing interact is larger than the usual scale of research on fire and grazing (Archibald et al. 2005), much of the research has until recently applied the two disturbances in a factorial arrangement of treatments (e.g., a single treatment and combination of treatments applied to an entire pasture) with little or no attention to the interaction of fire and grazing in space and time (e.g., spatially variable application of treatments within a pasture; Freckleton 2004; Fuhlendorf and Engle 2004). The grazing-fire interaction model argues that grazing and fire, interacting through a series of positive and negative feedbacks, results in a shifting mosaic of vegetation pattern across the landscape, reflecting evolutionary processes in Great Plains grasslands (Hobbs et al. 1991; Fuhlendorf and Engle 2001, 2004). The feedbacks influence probability of fire and probability of grazing by large ungulates, which in turn influence plant community composition and accumulated standing phytomass. The result is a diverse landscape that includes patches with variable histories of fire and grazing (Coppedge et al. 1998; Coppedge and Shaw 1998). Fuhlendorf and Engle (2004) tested this model with domestic cattle in North American tallgrass prairie and found the model correctly predicted that tall graminoids decrease in dominance and bare ground and herbaceous dicots increase in current burned patches that are focally grazed. These changes in composition and productivity are associated with a negative feedback because focal grazing reduces biomass, and therefore reduces the probability and intensity of fire, which in turn lowers the probability that the patch is grazed in the future. The grazing animal subsequently focuses on other patches burned more recently (Coppedge et al. 1998), and the tall graminoids eventually recover dominance, a positive feedback. Fuhlendorf and Engle (2004) validated the model's prediction that the firegrazing interaction results in a shifting mosaic of local patches that have been burned and heavily grazed dispersed within a patchwork of patches in various states of recovery. Perhaps the most striking implication of the model is that recovering patches (transitional patches) are unique to the fire-grazing interaction in that this patch type is absent, or essentially so, from traditionally managed grassland landscapes.

Heterogeneity associated with the fire-grazing model might provide habitat conditions necessary to conserve many grassland species including invertebrates. Grassland invertebrate community response to fire and grazing (see review by Swengel 2001) has been attributed largely to the influence on composition and structure of herbaceous biomass (Murdoch et al. 1972; Siemann 1998; Siemann et al. 1999) in which invertebrate abundance and richness are a function largely of species-specific responses to altered habitat conditions (Rice 1932; Nagel 1973; Hutchinson and King 1980; Rottman and Capinera 1983; Hansen 1986; Anderson et al. 1989; Welch et al. 1991; Molina et al. 1999). It follows that habitat conditions are reflected in invertebrate communities, but these studies of grassland invertebrates have almost exclusively decoupled fire and grazing. Researchers increasingly recognize the function of a full range of drivers of grassland habitat, including the fire-grazing interaction, for managing grassland vegetation and invertebrates (Vermeire et al. 2004; Branson et al. 2006). Hence, the importance to the invertebrate community of the ecological interaction of fire and grazing in space and time, as a coupled fire-grazing process, is receiving increased, deserved attention.
In this paper, we compare a heterogeneity-based approach to typical homogeneity-based rangeland management in the Great Plains to determine the extent to which patch burning followed by focal grazing influences aboveground invertebrate community organization. Our focus was not on the effects of fire or grazing in some factorial combination, but instead on the firegrazing ecological interaction and its effect on the invertebrate community. Our objective was to test the prediction that biomass and compositional variation of the invertebrate community will be greater in a heterogeneous habitat produced with patch burning as compared to traditional fire and grazing management that results in more homogeneous habitat.

\section{METHODS}

\section{Study Area and Experimental Design}

The study area is located on the Oklahoma State University Research Range, which has its headquarters (lat $36^{\circ} 3^{\prime} \mathrm{N}$; long $97^{\circ} 13^{\prime} \mathrm{W}$ ) about $21 \mathrm{~km}$ southwest of Stillwater, Oklahoma. The climate is continental with an average frost-free growing period of $204 \mathrm{~d}$ extending from April to October. Average annual precipitation is $831 \mathrm{~mm}$ with $65 \%$ as rain coming from May to October, and mean annual temperature is $15^{\circ} \mathrm{C}$ with average daily minimum of $-4.3^{\circ} \mathrm{C}$ in January and average daily maximum of $34^{\circ} \mathrm{C}$ in August. Major ecological sites are shallow prairie, loamy prairie, eroded prairie, and sandy savannah, with most of the area classified as tallgrass prairie and a few local communities representative of cross-timbers vegetation (Quercus stellata Wang. and Juniperus virginiana L.). Dominant grasses included little bluestem (Schizachyrium scoparium [Michx.] Nash), big bluestem (Andropogon gerardii Vitman), and indiangrass (Sorghastrum nutans [L.] Nash), and secondary grasses include switchgrass (Panicum virgatum L.), tall dropseed (Sporobolus asper [Michx.] Kunth), sideoats grama (Bouteloua curtipendula [Michx.] Torr.), and Scribner's dicanthelium (Dicanthelium oligosanthes [Schultes] Gould). Western ragweed (Ambrosia psilostachya D.C.) is the dominant forb. All pastures have been burned historically to minimize the encroachment of eastern redcedar (Juniperus virginiana L.; McCollum et al. 1999).

We used a completely randomized design with three replications of two grazing-fire treatments applied to pastures that varied in size from 45 to 65 ha. The treatments were 1) burning spatially distinct patches within a treatment pasture (Patch Burn), which is an approximation of the grazing-fire model (Fuhlendorf and Engle 2001) and 2) no burning with a treatment pasture (Traditional). Pastures of both treatments were treated similarly except for the application of spatially discrete fires in the Patch Burn treatment. Pastures were fenced to allow free movement of cattle and wildlife within each pasture. Pastures in both treatments were moderately stocked with mixed-breed yearling cattle from about 1 December to 1 September at $3 \mathrm{ha} \cdot$ animal $^{-1}$ based on long-term research projects to optimize sustainable production (McCollum et al. 1999). In both the Patch Burn treatments and Traditional treatments, the experimental unit consisted of a pasture divided into six distinct patches. Application of fires to patches within each Patch Burn treatment pasture was in sequential contiguous fashion to assure a 3-yr fire return interval. One-sixth of each 
pasture in the Patch Burn treatment was burned each spring (March to April) and one-sixth each summer-fall (July to October, hereafter referred to as fall). By summer of 2001, four patches in the Patch Burn treatment pastures had been burned. This resulted in three different patch types in the Patch Burn treatment pastures in the growing season of 2001: unburned patches, recently (current) burned patches (burned in the fall of 2000 and the spring of 2001), and transitional patches (burned in the fall of 1999 and the spring of 2000.

\section{Data Collection and Statistical Analyses}

Vegetation was sampled in late August and early September of 2001 within each patch within each pasture. Data consisted of canopy cover of plant functional groups, amount of bare ground, and cover of litter within $300.1-\mathrm{m}^{2}$ randomly located quadrats (180 per pasture). Data presented by Fuhlendorf and Engle (2004) did not distinguish among patch types within the Patch Burn treatment, so we present the data here. Additional detail about vegetation data can be found in Fuhlendorf and Engle (2004).

We collected invertebrates on $2 \mathrm{~d}$ in each of three periods (early, middle, and late) within the growing season of 2001. Two times during each period we performed 25 sweeps of a standard canvas beating net along each of two permanent transects centrally located within each of six patches within pastures of both treatments. This resulted in a total of 100 sweeps per patch for each sampling period. We defined a sweep through the herbaceous vegetation canopy as one full swing at full arm extension of the sweep net at each of 25 paces of the data collector along the transect. One person conducted all sweep sampling. The sweep net consisted of a 71-cm-deep canvas bag with a hoop opening surface area of $1140 \mathrm{~cm}^{2}$ attached to 91$\mathrm{cm}$-long handle. We restricted sampling to days with ambient temperature $>29^{\circ} \mathrm{C}$ and wind $<27 \mathrm{~km} \cdot \mathrm{h}^{-1}$. Sweep-net contents were emptied immediately after collection into labeled bags, placed on ice, and transferred to a freezer within $2 \mathrm{~h}$. Invertebrates were classified to order (Borrer et al. 1989) and weighed following drying samples in a forced-air oven at $50^{\circ} \mathrm{C}$ for $24 \mathrm{~h}$ and separating invertebrates from vegetation. We disregarded invertebrates sufficiently small to pass through a No. 20 sieve $(0.85 \mathrm{~mm}$; Klute 1994). Samples from the three sample periods were combined so that a sample represented the accumulated biomass collected over the three sample periods.

We used the invertebrate data to test the extent to which greater habitat diversity provided by the Patch Burn treatment as compared to the Traditional treatment affected aboveground invertebrates. Two management strategies (i.e., Patch Burn and Traditional) were applied to generate six potential treatment comparisons composed of a combination of treatment (Patch Burn and Traditional), patch type (current burned, transitional, and unburned), and season of burn (spring and fall). Patch type was considered a function of time since burning (TSB), in which TSB was $<12$ mo (current burned), 12 to 24 mo (transitional), or $3 \mathrm{yr}$ (unburned). All treatment pastures in the study were burned in 1998, so that at the time of the study, the two unburned patches in the Patch Burn pastures and all six patches in the Traditional pastures had not been burned since 1998.

Data analyses consisted of both univariate and multivariate statistics. The multivariate technique was principal component analysis (PCA), an indirect gradient analysis and unconstrained ordination, to extract dominant patterns in the entire invertebrate community data set (McGarigal et al. 2000). We used PCA site scores to evaluate the effect of treatment on the invertebrate community as a whole. The univariate data consisted of total invertebrate biomass and biomass for the four most abundant invertebrate orders. We subjected the univariate data to analysis of variance in SAS PROC GLM (SAS Institute 2001), and using a protected F-test (i.e., presence of a treatment effect, $P<0.05$ ) we subsequently used the pdiff option to contrast biomass in each patch within Patch Burn pastures with biomass in the Traditional treatment pasture. Patch contrasts were considered significant at $P<0.05$ unless otherwise noted. For both the univariate and multivariate techniques we computed mean and standard error for patch type within the Patch Burn treatment and for the Traditional treatment. Thus, the robust design allowed us to test if any of the patches in Patch Burn pastures produced more total invertebrate biomass and more biomass in each of four orders compared to Traditional pastures.

\section{RESULTS}

Variation in vegetation between treatments and among patches within the Patch Burn pastures reflected different stages of recovery as a function of TSB (Table 1). Within Patch Burn pastures, forb cover peaked in current burned patches and in transitional patches whereas current burned patches contained about 20 times more bare ground than Traditional pastures (Table 1). Litter cover varied by almost a factor of four between current burned patches in Patch Burn pastures and Traditional pastures, but litter cover and bare ground did not differ between unburned patches in Patch Burn pastures and Traditional pastures. Litter cover in transitional patches in the Patch Burn pastures was about half that of Traditional pastures.

Total invertebrate mass was about $50 \%$ greater in transitional patches within Patch Burn pastures $(P<0.01$ and $P<0.08$, spring-burned transitional and fall-burned transitional patches, respectively) as compared to the Traditional pastures (Fig. 1). However, total invertebrate biomass in current burned patches in the Patch Burn pastures was about one-third less than total invertebrate biomass in Traditional pastures $(P<0.09$ and $P<0.05$, fall-burned and spring-burned current burned patches, respectively; Fig. 1). Biomass of Orthoptera and Hemiptera either was greater in transitional patches in the Patch Burn pastures as compared to the Traditional pastures (Orthoptera, $P<0.01$ spring-burned transitional patches; Hemiptera, $P<0.01$ and $P<0.04$, spring-burned transitional patches and fall-burned transitional patches, respectively) or did not differ from the Traditional pastures (Orthoptera, $P<0.18$ fall-burned transitional patches). Arachnida was less abundant in current burned spring patches $(P<0.01)$ and unburned patches $(P<0.04)$ in Patch Burn pastures as compared to Traditional pastures (Fig. 2). No treatment effect was detected for Homoptera $(P<0.05)$, and Homoptera biomass in transitional patches of the Patch Burn pastures was equivalent to that of the Traditional pastures. Orthoptera biomass in spring-burned 
Table 1. Canopy cover (mean and standard error) of plant functional groups, cover of litter, and amount of bare ground in patches within the Patch treatment and within the Traditional treatment.

Patch burn

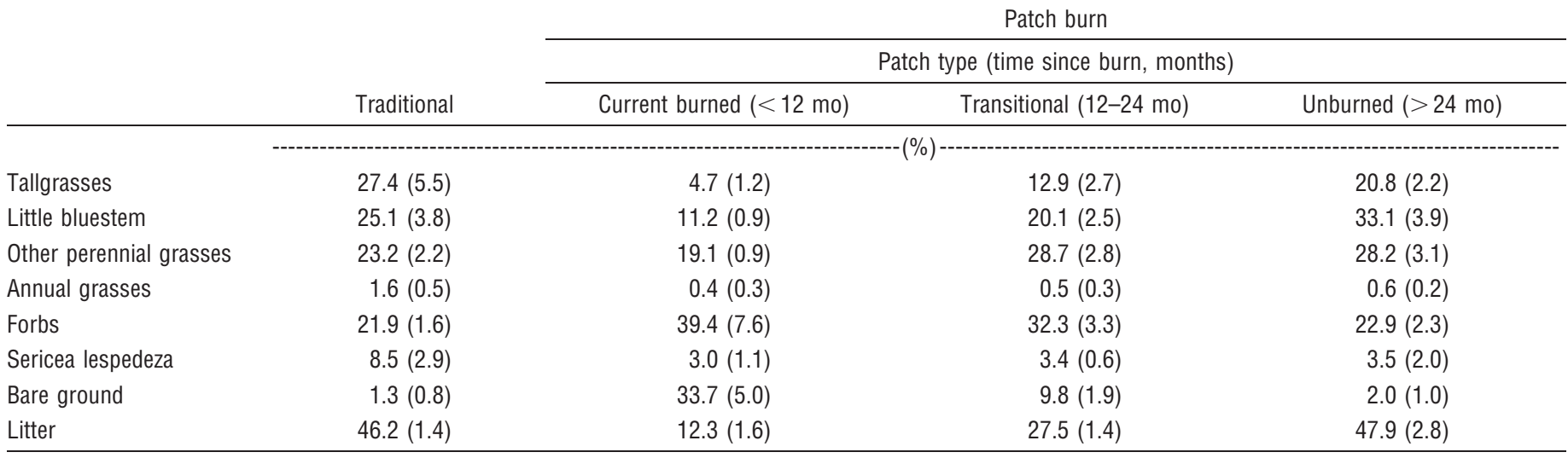

transitional patches was greater by almost an order of magnitude than the next most abundant order of invertebrates in any other patch type and the Traditional pastures.

PCA ordination provided additional evidence that differences in community composition of patch types of the Patch Burn pastures as compared to Traditional pastures were associated largely with abundance of Orthoptera (Fig. 3). We interpreted axis 1 of the ordination as largely a function of Orthoptera. Greater abundance of Orthoptera was associated with more positive PCA axis-1 scores (average axis-1 site score for Orthoptera was 1.5) and specifically with transitional patches (with axis-1 scores >1.5) in Patch Burn pastures. Current burned patches in Patch Burn pastures and unburned patches in Patch Burn pastures, with axis-1 scores as low as -2 , did not contain more Orthoptera than Traditional treatment pastures

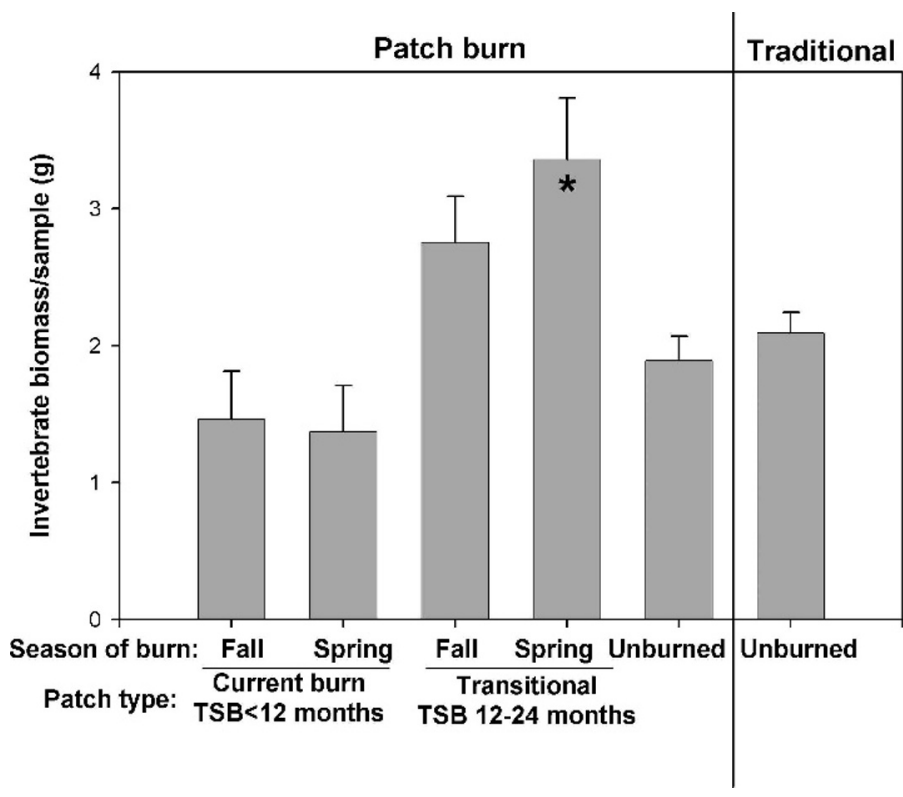

Figure 1. Total biomass of invertebrates over three sample periods in 2001 in Traditional (unburned) treatment pastures and patches within Patch Burn treatment pastures arranged by season of burn within patch type, which differed by time since burning (TSB). Vertical lines represent one standard error. Bars containing an asterisk $\left({ }^{*}\right)$ differ from the Traditional unburned treatment pastures $(P<0.05)$.
(Fig. 2), so their compositional differences compared to the Traditional treatment pastures were largely a function of differences in abundance of invertebrates other than Orthoptera. Therefore, patches in different stages of recovery following burning and focal grazing within the Patch Burn differed in invertebrate community composition relative to invertebrate community composition of Traditional pastures (Fig. 3). Community composition of patches within Patch Burned pastures varied relative to community composition in the Traditional pastures, which reflects heterogeneity in habitat provided in the Patch Burned pastures (Table 1). Therefore, as compared to traditional management, patch burning increased overall variation in the composition of the invertebrate community.

\section{DISCUSSION}

Consistent with the fire-grazing interaction model (Fuhlendorf and Engle 2001) and verifying the prediction we hypothesized, invertebrate community composition and invertebrate mass were sensitive to habitat heterogeneity provided by patch burning. As compared to the Traditional pastures, patches within Patch Burn pastures differed in invertebrate mass and the compositional contributions by various orders of invertebrates on the basis of time since burning and focal grazing. The response of invertebrates to fire and grazing is quite well developed (see review by Swengel 2001), but in contrast to experiments in which grazing and fire are applied independently or as a factorial combination of treatments (Swengel 2001; Freckleton 2004), as is the case at Konza Prairie in Kansas (Knapp et al. 2004), the Patch Burn treatment in our study coupled fire and grazing as a dynamic interaction (Fuhlendorf and Engle 2001; Archibald et al. 2005). Increased habitat heterogeneity (Fuhlendorf and Engle 2004) can be said to differentiate patch burning from the decoupled effects of fire or grazing, and we show here that the resulting habitat heterogeneity is reflected in the invertebrate community. This result is all the more striking given that we identified invertebrates only to order, which likely underreports the diversity and specificity of invertebrate taxa response to habitat heterogeneity.

Invertebrate abundance and community composition in grasslands are a function of herbaceous vegetation (biomass, 

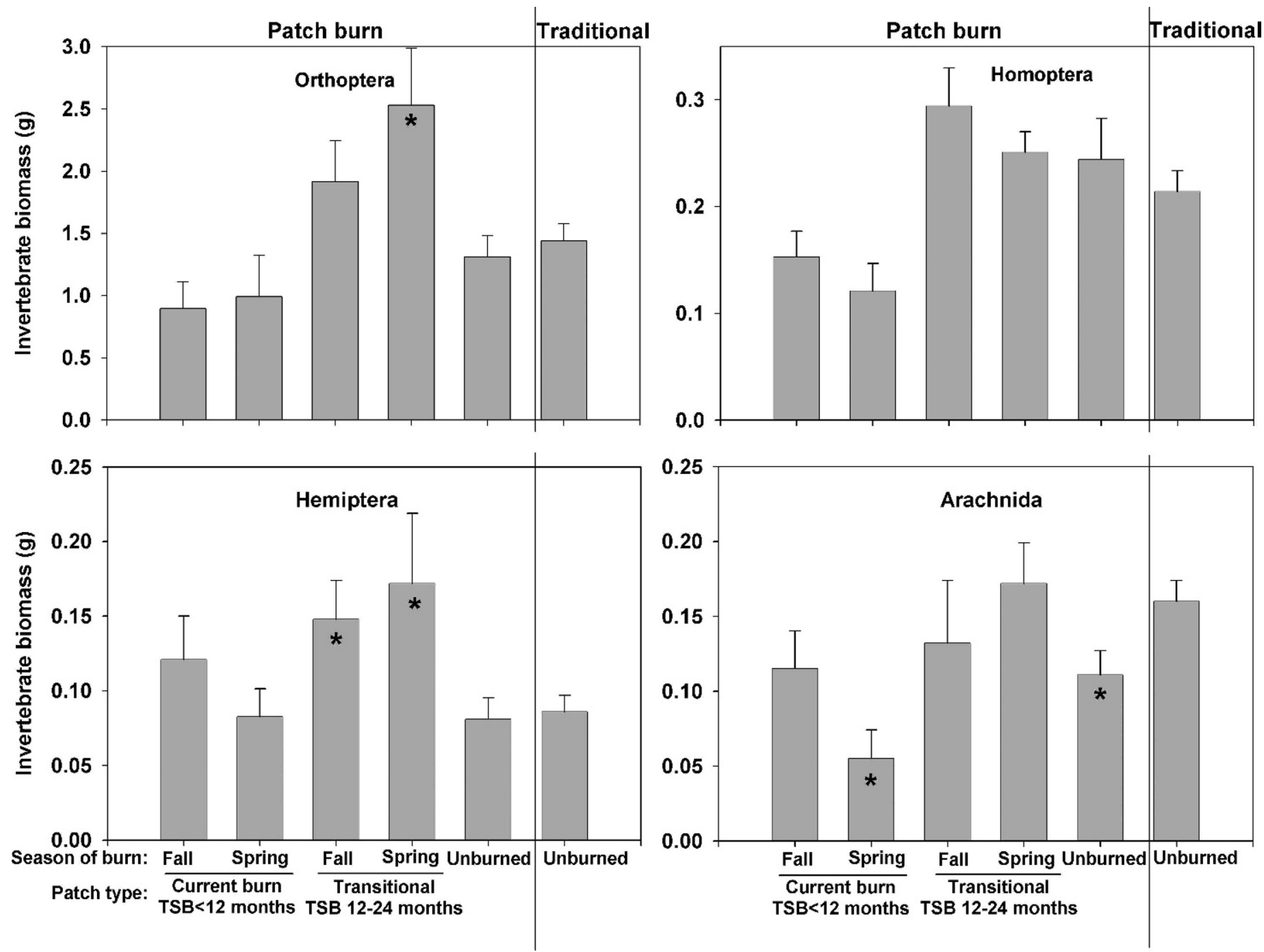

Figure 2. Biomass of the four most abundant invertebrate orders over three sample periods in 2001 in Traditional (unburned) treatment pastures and patches within Patch Burn treatment pastures arranged by season of burn within patch type, which differ by time since burning (TSB). Vertical lines represent one standard error. Bars containing an asterisk $\left({ }^{*}\right)$ differ from the traditional treatment $(P<0.05)$.

plant structural diversity, and composition) (Southwood et al. 1979; Morris 1981) and plant tissue quality (Strong et al. 1984). Our results contrast with those of most studies in which fire and grazing reduced invertebrate mass (e.g., Hutchinson and King 1980) because plant biomass strongly influences invertebrate abundance in systems that are resource limited (Ritchie 2000). Heavy grazing and fire produce a simplifying effect, i.e., lower invertebrate species richness and abundance because of simplified plant architecture (Tscharntke and Greiler 1995) and reduced heterogeneity and therefore reduces niches and resources for invertebrates (Southwood et al. 1979; Van Wieren 1998; Rambo and Faeth 1999; Cagnolo et al. 2002).

Unlike with heavy grazing or fire alone, the opposite is likely true in patches recovering from focal burning and grazing (i.e., transitional patches) because transitional patches contain structure, plant species, and resources (e.g., accumulating plant litter) absent under decoupled fire and grazing (Fuhlendorf and Engle 2004). This also is consistent with the general view that invertebrate diversity is a function of complexity of plant structure and plant species diversity (Murdoch et al. 1972; Siemann 1998; Siemann et al. 1999; Haddad et al. 2001; Cagnolo et al. 2002; Joern 2005) because invertebrates select habitat on the basis of both plant taxa (Southwood et al. 1979) and plant structure (Dennis et al. 1998). Current burned, heavily grazed patches and transitional, recovering patches in Patch Burn pastures provide elements of habitat largely absent from unburned and grazed grassland habitat, which is common in this region (Table 1; Fuhlendorf and Engle 2004). Aside from resource availability and its effect on habitat suitability, other factors including direct mortality, posttreatment stress, and the ability to repopulate a burned and grazed area also might explain the effects of our treatments on invertebrates (Swengel 2001).

That not all patches within the Patch Burn pastures differed in the same manner from Traditional pastures in mass and composition of invertebrates presents a compelling case for the ecological role of heterogeneity in structuring invertebrate communities. Moreover, these results support the value of complexity in imposition of the fire-grazing interaction to 


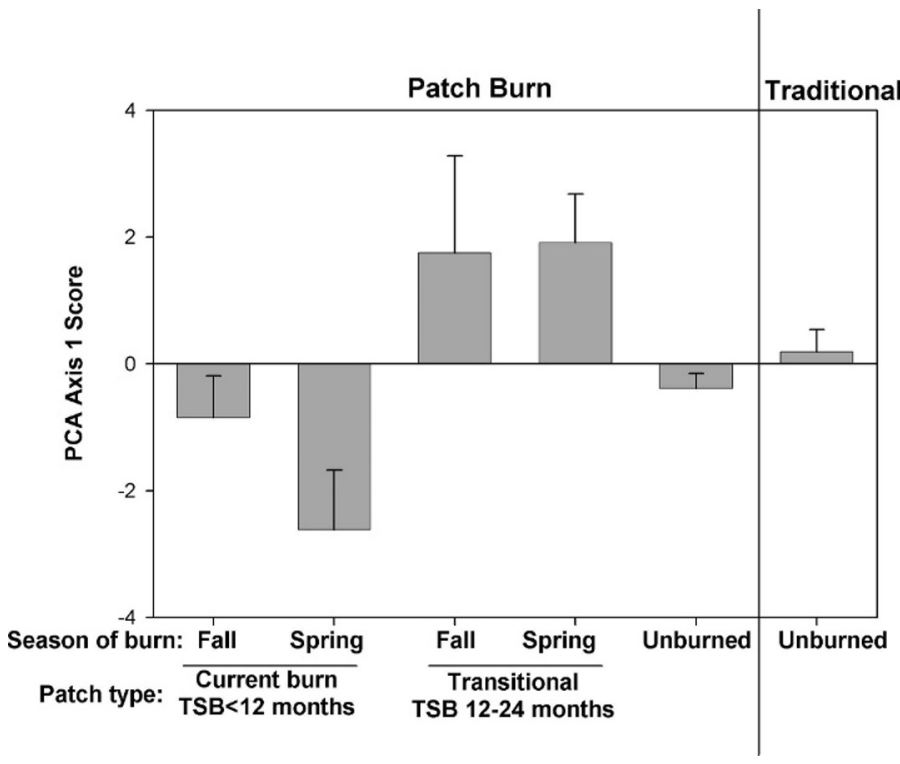

Figure 3. Scores for the first axis of the principle component analysis (PCA) in which values represent mean PCA scores for patch type within the Patch Burn treatment and the mean plot score for the Traditional (unburned) treatment. Treatment pastures are arranged by season of burn within patch type, which differ by time since burning (TSB). Vertical lines represent one standard error based on sites scores of three replications in each treatment. The first two axes of the PCA accounted for $40 \%$ of the variance in the data, and PCA axis 1 and PCA axis 2 (not shown) had eigenvalues of 3.89 and 2.10 , respectively.

enhance natural heterogeneity. An important application is that the transitional patch within Patch Burn pastures is possible solely through imposition of the fire-grazing interaction, which creates a high-intensity focal disturbance that subsequently recovers when the focal disturbance is shifted to a new patch. The upside is that the fire-grazing interaction provides greater managerial leverage for enhancing heterogeneity in both space and time than would be possible if fire and grazing were applied to an entire pasture in any combination of the two disturbances (i.e., either fire or grazing alone or fire and grazing combined). Indeed, response of several orders of invertebrates and total mass of invertebrates to TSB corresponds to change in plant functional groups (i.e., grasses increase, forbs decrease), litter (i.e., increases), and bare ground (i.e., decreases; Table 1; Fuhlendorf and Engle 2004).

Several orders of invertebrates were sensitive to season of burning even though composition of plant functional groups, litter, or bare ground varied little with season of burning (Fuhlendorf and Engle 2004). For example, Arachnida mass in current-burned, spring-burned patches was less than in Traditional pastures but Arachnida mass did not differ between current-burned, fall-burned patches and Traditional pasture. Swengel (2001) summarized the few studies investigating fire season and concluded that differential responses to season of fire in grassland might be explained on the basis of stage of activity of species (e.g., diapause within a protected microhabitat) and on the indirect effects of resource removal during a sensitive stage of a species need for habitat. Joern (2004), summarized the complex influence of burning and grazing in tallgrass prairie on grasshopper (Orthoptera: Acrididae) abundance as determined by current weather conditions interacting with the influence of habitat structure on food quality, escape space, and thermoregulation of grasshoppers. As is the case with other invertebrates, ant assemblages in South African savannah are less sensitive to kind of fire (e.g., seasonality, fire-return interval, etc.) than to whether or not fire is imposed, and although responses are species-dependent, bare ground and litter are key factors that influence ants (Parr et al. 2004).

Because invertebrates are often responsive to compositional change in the plant community resulting from management that includes burning (Evans 1984; Evans and Seastedt 1995; Fay 2003), season of burn might influence invertebrate habitat quality in this rangeland if plant composition differed between fall and spring fires. Although different seasons of burning in tallgrass prairie has been viewed to differentially favor forbs and grasses (Launchbaugh and Owensby 1978), the response is neither prominent nor consistent (Engle and Bidwell 2001). Moreover, plant community response to season of burn is both species-specific and site-specific (Towne and Kemp 2003), and the influence of season of fire interacts with grazing (Coppedge et al. 1998; Fuhlendorf and Engle 2004). Forbs and legumes that exhibit the $\mathrm{C}_{3}$ photosynthetic pathway are potentially major contributors to invertebrate habitat quality on rangelands dominated by $\mathrm{C}_{4}$ grasses (Haddad et al. 2001; Fay 2003). This might happen in part because when forbs are present, some invertebrates might well avoid feeding on $\mathrm{C}_{4}$ grasses and therefore respond positively to patches with more forbs (Caswell and Reed 1976). However, we found no difference in composition of plant functional groups between patches burned in the fall and spring in the Patch Burn treatment in our study (Fuhlendorf and Engle 2004). Subtle differences in spatial or temporal pattern of host plants between fall-burned and spring-burned patches might influence habitat colonization and use by invertebrates (Evans and Seastedt 1995) especially by those limited by dispersal capability (Kruess and Tscharntke 2002). Minor change in microclimate associated with difference in burn date also might change several variables important to invertebrate feeding and reproductive behavior (Evans and Seastedt 1995), and specialist invertebrates might exploit genera or families of forbs or other minor components of the vegetation (Haddad et al. 2001) that we were unable to detect. Thus, our data provided evidence that even when the interactive effects of fire and grazing are not obvious in vegetation composition and structure, indirect effects can be expressed in the invertebrate community so that a mosaic of burn patches differing in season and time since burning add meaningfully to compositional complexity of the invertebrate community.

\section{MANAGEMENT IMPLICATIONS}

The shifting mosaic created by the Patch Burn treatment provides habitat that meets requirements for a broad range of invertebrate species. Allowing $2 \mathrm{yr}$ for recovery from fire, patch burning is compatible with conservation of invertebrate biodiversity of rangeland, and therefore presents a potentially useful tool for managing prairie with fire and grazing to achieve an array of management objectives (e.g., sustainable livestock grazing enterprises, controlling woody plant invasion, and 
enhancing biodiversity and wildlife habitat). Under traditional management in the unfragmented tallgrass prairie of the Flint Hills of North America, fire and grazing simplify vegetation composition and structure, a feature common to extensive grasslands elsewhere in the world (Fuhlendorf and Engle 2001; Archibald et al. 2005). Appeals for managers to consider the value of natural heterogeneity (Pastor et al. 1997; Freckleton 2004) are supported by our results that demonstrate the interaction of fire and grazing can enhance habitat heterogeneity to benefit an important animal assemblage. Patch burning has the potential to increase rangeland area under management for conservation purposes other than livestock production because greater invertebrate biomass and diversity are likely to benefit other native animals, including birds, in the food chain (Ricklefs 1974; O’leske et al. 1997).

Concern about using fire or grazing in isolated remnant habitats in which declining species of invertebrates and other fire-sensitive species are vulnerable to removal of vegetative cover is a commonly voiced concern (Panzer and Schwartz 2000) even when grazing and fire are essential to provide habitat required of invertebrate species that are prairie specialists (Swengel and Swengel 2001). However, the point at which habitat heterogeneity becomes habitat fragmentation (Tews et al. 2004) for invertebrates deserves investigation. All habitat can not be viewed as usable space from the perspective of a habitat-selective organism (Guthery 1999). However, fragmentation in the traditional sense is arguably not applicable to perennial grassland until a grassland is fragmented by change in land cover to something other than grassland (Woodward et al. 2001). Furthermore, a shifting mosaic across a grassland landscape provides habitat diversity for grassland species that would potentially be absent were it not for the added diversity of habitat, i.e., the habitat heterogeneity hypothesis (Haddad et al. 2001; Jonas et al. 2002; Fay 2003).

\section{ACKNOWLEDGMENTS}

We thank John Wier, Timothy Tunnell, Chris Stansberry, and Chad Cummings for contributing to treatment application and for collecting vegetation data. Don Arnold's help with identification of invertebrates made this work possible.

\section{LITERATURE CITED}

Anderson, R. C., T. Leahy, and S. S. Dhillion. 1989. Numbers and biomass of selected insect groups on burned and unburned sand prairie. American Midland Naturalist 122:151-162.

Archibald, S., and W. J. Bond. 2004. Grazer movements: spatial and temporal responses to burning in a tall-grass African savanna. International Journal of Wildland Fire 13:377-385.

Archibald, S., W. J. Bond, W. D. Stock, and D. H. K. Falrbanks. 2005. Shaping the landscape: fire-grazer interactions in an African savanna. Ecological Applications 15:96-109.

Borrer, D. J., C. A. Triplehorn, and N. F. Johnson. 1989. An introduction to the study of insects. 6th ed. Fort Worth, TX, USA: Saunders College Publishing. $800 \mathrm{p}$.

Branson, D. H., A. Joern, and G. A. Sword. 2006. Sustainable management of insect herbivores in grassland ecosystems: new perspectives in grasshopper control. BioScience 56:743-755.
Cagnolo, L., S. I. Molina, and G. R. Valladares. 2002. Diversity and guild structure of insect assemblages under grazing and exclusion regimes in a montane grassland from central Argentina. Biodiversity and Conservation 11:407-420.

Caswell, H., and F. C. Reed. 1976. Plant-herbivore interactions. The indigestibility of $\mathrm{C}_{4}$ bundle sheath cells by grasshoppers. Oecologia 26:151-156.

Coluins, S. L. 1992. Fire frequency and community heterogeneity in tallgrass prairie: a field experiment. Ecology 73:2001-2006.

Coppedge, B. R., D. M. Engle, S. D. Fuhlendorf, R. E. Masters, and M. S. Gregory. 2001. Landscape cover type and pattern dynamics in fragmented southern Great Plains grasslands, USA. Landscape Ecology 16:677-690.

Coppedge, B. R., D. M. Engle, C. S. Toepfer, and J. H. Shaw. 1998. Effects of seasonal fire, bison grazing and climatic variation on tallgrass prairie vegetation. Plant Ecology 139:235-246.

Coppedge, B. R., And J. H. Shaw. 1998. Bison grazing patterns on seasonally burned tallgrass prairie. Journal of Range Management 51:258-264.

Coppock, D. L., AND J. K. Detuing. 1986. Alteration of bison and black-tailed prairie dog grazing interaction by prescribed burning. Journal of Wildlife Management 50:530-542.

Dennis, P., M. R. Yourn, and I. J. Gordon. 1998. Distribution and abundance of small insects and arachnids in relation to structural heterogeneity of grazed, indigenous grasslands. Ecological Entomology 23:253-264.

DuvalL, V. L., AND L. B. Whitaker. 1964. Rotation burning: a forage management system of longleaf pine-bluestem ranges. Journal of Range Management 17: 322-326.

Engle, D. M., and T. G. Bidwell. 2001. Viewpoint: the response of central North American prairies to seasonal fire. Journal of Range Management 54:2-10.

Evans, E. W. 1984. Fire as a natural disturbance to grasshopper assemblages of tallgrass prairie. Oikos 43:9-16.

Evans, E. W., and T. R. SeAstedt. 1995. The relations of phytophagous invertebrates and range plants. In: D. S. Bedunah [ED.]. Rangeland plant morphology and physiology. Denver, CO, USA: Society for Range Management. p. 580-634.

FAY, P. A. 2003. Insect diversity in two burned and grazed grasslands. Environmental Entomology 32:1099-1104.

Forde, J. D., N. F. SLOAN, And D. A. Shown. 1984. Grassland habitat management using prescribed burning in Wind Cave National Park, South Dakota. Prairie Naturalist 16:97-110.

FreCKLeton, R. P. 2004. Editorial: the problems of prediction and scale in applied ecology: the example of fire as a management tool. Journal of Applied Ecology 41:599-603.

Funlendorf, S. D., And D. M. Engle. 2001. Restoring heterogeneity on rangelands: ecosystem management based on evolutionary grazing patterns. BioScience 68:625-632.

Funlendorf, S. D., And D. M. Engle. 2004. Application of the fire-grazing interaction to restore a shifting mosaic in tallgrass prairie. Journal of Applied Ecology 41:604-614.

Funlendorf, S. D., AND F. E. Smeins. 1999. Scaling effects of grazing in a semi-arid savanna. Journal of Vegetation Science 10:731-738.

GutheRY, F. S. 1999. Slack in the configuration of habitat patches for northern bobwhites. Journal of Wildlife Management 63:245-250.

Haddad, N. M., D. Tilman, J. Haarstad, M. Ritchie, and J. Knops. 2001. Contrasting effects of plant richness and composition on insect communities: a field experiment. American Naturalist 158:17-35.

Hansen, J. H. 1986. Comparison of insects from burned and unburned areas after a range fire. Great Basin Naturalist 46:721-727.

HobBs, R. J., D. S. Schimel, C. E. Owensby, and D. S. OJima. 1991. Fire and grazing in the tallgrass prairie: contingent effects on nitrogen budgets. Ecology 72:13741382.

Hutchinson, K. J., and K. L. King. 1980. The effects of sheep stocking level on invertebrate abundance, biomass and energy utilization in a temperate, sown grassland. Journal of Applied Ecology 17:369-387.

Joern, A. 2004. Variation in grasshopper (Acrididae) densities in response to fire frequency and bison grazing in tallgrass prairie. Environmental Entomology 33:1617-1625.

JoERn, A. 2005. Disturbance by fire frequency and bison grazing modulate grasshopper assemblages in tallgrass prairie. Ecology 86:861-873. 
Jonas, J. L., M. R. Whiles, and R. E. Charlton. 2002. Aboveground invertebrate responses to land management differences in a central Kansas grassland. Environmental Entomology 31:1142-1152.

KLUTE, D. S. 1994. Avian community structure, reproductive success, vegetative structure, and food availability [thesis]. Manhattan, KS, USA: Kansas State University. $168 \mathrm{p}$.

Knapp, A. K., M. D. Smith, S. L. Collins, N. Zambatis, M. Peel, S. Emery, J. Wojdak, and M. C. Horner-Devine. 2004. Generality in ecology: testing North American grassland rules in South African savannas. Frontiers in Ecology and the Environment 2:483-491.

Kruess, A., and T. TscharntKe. 2002. Contrasting responses of plant and insect diversity to variation in grazing intensity. Biological Conservation 106:293302.

Launchbaugh, J. L., and C. E. Owensby. 1978. Kansas rangelands: their management based on a half century of research. Manhattan, KS, USA: Kansas Agricultural Experiment Station Bulletin 622. $56 \mathrm{p}$.

McCollum, F. T. III, R. L. Gillen, B. R. Karges, and M. E. Hodges. 1999. Stocker cattle response to grazing management in tallgrass prairie. Journal of Range Management 52:120-126.

McGarigal, K., S. Cushman, and S. Stafford. 2000. Multivariate statistics for wildlife and ecology research. New York, NY, USA: Springer. 283 p.

Moe, S. R., P. WegGe, and K. B. KapelA. 1990. The influence of man-made fires on large wild herbivores in Lake Burungi area in northern Tanzania. African Journal of Ecology 28:35-43.

Molina, S. I., G. R. Valladares, S. Gardner, and M. R. Cabido. 1999. The effects of logging and grazing on the insect community associated with a semi-arid chaco forest in central Argentina. Journal of Arid Environments 42:29-42.

MorRIs, M. G. 1981. Responses of grassland invertebrates to management by cutting. III. Adverse effects on Auchenorhyncha. Journal of Applied Ecology 18:107-123.

Murdoch, W. W., F. C. Evans, and C. H. Peterson. 1972. Diversity and pattern in plants and insects. Ecology 53:819-821.

NAGEL, H. G. 1973. Effect of spring burning on herbivorous and non-herbivorous arthropod populations. Journal of Kansas Entomological Society 46:485-496.

O'Ieske, D. L., R. J. RobeL, And K. E. Kemp. 1997. Sweepnet-collected invertebrate biomass from high- and low-input agricultural fields in Kansas. Wildlife Society Bulletin 25:133-138.

Panzer, R., and M. Schwartz. 2000. Effects of management burning on prairie insect species richness with a system of small, highly fragmented reserves. Biological Conservation 96:363-369.

Parr, C. L., H. G. Robertson, H. C. Biggs, and S. L. Chowns. 2004. Response of African savanna ants to long-term fire regimes. Journal of Applied Ecology 41:630-642.

Pastor, J., R. Moen, and Y. Cohen. 1997. Spatial heterogeneities, carrying capacity, and feedbacks in animal-landscape interactions. Journal of Mammalogy 78 : 1040-1052.

Pickett, S. T. A., M. L. Cadenasso, and T. L. Benning. 2003. Biotic and abiotic variability as key determinants of savanna heterogeneity at multiple spatiotemporal scales. In: J. T. De Toit, K. H. Rogers, and H. Biggs [EDS.] The Kruger experience: ecology and management of savanna heterogeneity. Washington, DC, USA: Island Press. 519 p.

Rambo, J. L., AND S. H. Faeth. 1999. Effect of vertebrate grazing on plant and insect community structure. Conservation Biology 13:1047-1054.
RICE, L. A. 1932. The effect of fire on the prairie animal communities. Ecology 13:392-401.

RICKLEFS, R. E. 1974. Energetics of reproduction in birds. In: R. A. Paynter [ED.]. Avian energetics. Cambridge, MA, USA: Publications of the Nuttall Ornithological Club, no. 15. p. 152-292.

RitchiE, M. E. 2000. Nitrogen limitation and trophic versus abiotic influences on insect herbivores in a temperate grassland. Ecology 81:1601-1612.

Rottman, R. J., and J. L. Capinera. 1983. Effects of insect and cattle-induced perturbations on a shortgrass prairie arthropod community. Journal of the Kansas Entomological Society 56:241-252.

SAS InStitute. 2001. SAS/STAT User's Guide. Version 8. Cary, NC, USA: SAS Institute. 3848 p.

SIEMANn, E. 1998. Experimental tests of effects of plant productivity and diversity on grassland arthropod diversity. Ecology 76:2057-2070.

Siemann, E., J. HaArstad, and D. Tilman. 1999. Dynamics of plant and arthropod diversity during old field succession. Ecography 22:406-414.

Southwood, T. R. E., V. K. Brown, and P. M. Reader. 1979. The relationship of plant and insect diversities in succession. Biological Journal of the Linnean Society $12: 327-348$

Strong, D. R., JR., J. H. Lawton, and T. R. E. Southwood. 1984. Insects on plants: community patterns and mechanisms. Cambridge, MA, USA: Harvard University Press. 313 p.

Swenget, A. B. 2001. A literature review of insect responses to fire, compared to other conservation managements of open habitat. Biodiversity and Conservation 10:1141-1169.

Swengel, A. B., And S. R. Swengel. 2001. Effects of prairie and barrens management on butterfly faunal composition. Biodiversity and Conservation 10:1757-1785.

Tews, J., U. Brose, V. Grimm, K. Tielborger, M. C. Wichmann, M. Schwager, and F. JeLTSCH. 2004. Animal species diversity driven by habitat heterogeneity/ diversity: the importance of keystone structures. Journal of Biogeography 31:79-92.

Towne, E. G., And K. E. Kemp. 2003. Vegetation dynamics from annually burned tallgrass prairie in different seasons. Journal of Range Management 56:185192

Tscharntke, T., and H. J. Greiler. 1995. Insect communities, grasses, and grasslands. Annual Review of Entomology 40:535-558.

Van Wieren, S. E. 1998. Effects of large herbivores upon the animal community. In: M. F. WallisDeVries, J. P. Baker, and S. E. Van Wieren [EDS.]. Grazing and conservation management. Dordrecht, Netherlands: Kluwer Academic Publishers. p. 185-213.

Vermeire, L. T., R. B. Mitchell, S. D. Fuhlendorf, and D. B. Wester. 2004. Selective control of rangeland grasshoppers with prescribed fire. Journal of Range Management 57:29-33.

Welch, J. L., R. Redak, and B. C. KondratiefF. 1991. Effect of cattle grazing on density and species of grasshoppers (Orthoptera: Acrididae) of the central plains experimental range in northern Colorado: a reassessment after two decades. Journal of the Kansas Entomological Society 64:337-343.

WILSEY, B. J. 1996. Variation in use of green flushes following burns among African ungulate species: the importance of body size. African Journal of Ecology 34:32-38

Woodward, A. J. W., S. D. Fuhlendorf, D. M. Leslie, JR., and J. Shackford. 2001. Influence of landscape composition and change on lesser prairie-chicken populations. American Midland Naturalist 145:261-274. 